\title{
Pengembangan Potensi Ekonomi Desa dalam Upaya Meningkatkan Ekonomi Masyarakat Melalui Badan Usaha Milik Desa
}

\author{
Tarmidzi \& Ifka Arismiyati \\ Institut Agama Islam Negeri Pekalongan \\ Email : tarmidzipkl@gmail.com
}

\begin{abstract}
Village Owned Enterprises (BUMDes) are an alternative to improve rural economies. BUMDes was born as a new approach in efforts to improve the village economy based on the needs and potential of the village. The management of BUMDes is fully carried out by the village community, namely from the village, by the village, and for the village. Babalan Lor Village, Bojong Subdistrict, Pekalongan Regency, is currently forming BUMDes as a community economic institution. If viewed from its potential, this village has great potential for the establishment of BUMDes as a place to accommodate the economic activities of the community and public service institutions in the community. This study aims to explore the Village Potential to be managed by VillageOwned Enterprises in order to improve the welfare of the community. This research uses Community Based Research method, in which the research is carried out in several stages, namely: in-depth interview with participants who are key actors in the BUMDes, the next stage conducts Group Discussion based on the interest groups in the village, and in the final stage Focus Group Discussion where discussions are carried out by various interested parties. The results of this study indicate that the potential of the Village that can be managed by BUMDes is expected to bring about changes in the economic and social fields.
\end{abstract}

Abstrak: Badan Usaha Milik Desa (BUMDes) merupakan salah satu alternatif untuk meningkatkan ekonomi di pedesaan. BUMDes lahir sebagai suatu pendekatan baru dalam usaha peningkatan ekonomi desa berdasarkan kebutuhan dan potensi desa. Pengelolaan BUMDes sepenuhnya dilaksanakan oleh masyarakat desa, yaitu dari desa, oleh desa, dan untuk desa. Desa Babalan Lor Kecamatan Bojong Kabupaten Pekalongan, saat ini baru membentuk BUMDes sebagai lembaga perekonomian masyarakat. Jika dilihat dari potensinya, Desa ini memiliki potensi besar untuk berdirinya BUMDes sebagai penampung kegiatan-kegiatan ekonomi masyarakat dan lembaga pelayanan publik masayarakat. Penelitian ini bertujuan untuk menggali Potensi Desa untuk dikelola Badan Usaha Milik Desa dalam rangka meningkatkan kesejahteraan masyarakat. Penelitian ini menggunakan metode Community Based Research, di mana penelitian dilakukan dalam beberapa tahap, yaitu: in-depth interview dengan partisipan yang menjadi aktor kunci dalam BUMDes, tahap selanjutnya melakukan Diskusi Kelompok berdasarkan kelompok kepentingan yang ada di desa tersebut, dan pada tahap akhir dilakukan Focus Group Discussion dimana 
diskusi dilakukan oleh berbagai pihak yang berkepentingan. Hasil dari penelitian ini menunjukkan potensi Desa yang dapat dikelola BUMDes yang diharapkan dapat membawa perubahan di bidang ekonomi dan sosial.

Kata Kunci: BUMDes, potensi, ekonomi

\section{PENDAHULUAN}

Kabupaten Desa merupakan unit terkecil dari negara yang terdekat dengan masyarakat dan secara riil langsung menyentuh kebutuhan masyarakat untuk disejahterakan. Menurut Undang-Undang Desa (UU Nomor 6 Tahun 2014) Desa adalah kesatuan masyarakat hukum yang memiliki batas wilayah, yang berwenang untuk mengatur dan mengurus urusan pemerintahan, kepentingan masyarakat setempat berdasarkan prakarsa masyarakat, hak asal usul, dan/atau hak tradisional yang diakui dan dihormati dalam sistem pemerintahan Negara Kesatuan Republik Indonesia (NKRI). Sebagai wakil negara, desa wajib melakukan pembangunan baik pembangunan fisik maupun pembanguan sumber daya manusia, sebagai upaya peningkatan kualitas hidup dan kehidupan untuk sebesar-besarnya kesejahteraan masyarakat desa.

Pertumbuhan ekonomi desa seringkali dinilai lambat dibandingkan pembangunan ekonomi perkotaan. Untuk meningkatkan hal tesebut dibutuhkan dua pendekatan yaitu: a) Kebutuhan masyarakat dalam melakukan upaya perubahan dan mencegah hal-hal yang tidak diinginkan, dan b) Political will dan kemampuan pemerintah desa bersama masyarakat dalam mengimplementasikan perencanaan pembangunan yang sudah disusun (Rutiadi, 2001 dalam Bachrein, 2010).

Salah satu upaya yang bisa dilakukan adalah dengan mendorong gerak ekonomi desa melalu kewirausahaan desa, dimana kewirausahaan desa menjadi strategi dalam pengembangan dan pertumbuhan kesejahteraan (Ansari, 2016). Kewirausahaan desa ini dapat ditampung dalam Badan Usaha Milik Desa (BUMDes) yang dikembangkan oleh pemerintah maupun masyarakat desa (Prabowo, 2014). BUMDes adalah badan usaha yang seluruh atau sebagian besar modalnya dimiliki oleh desa melalui penyertaan langsung yang berasal dari kekayaan desa yang dipisahkan guna mengelola aset, jasa pelayanan, dan usaha lain untuk sebesar-besarnya kesejahteraan masyarakat desa (UU Nomor 32 Tahun 2004). Hal tersebut semakin didukung oleh pemerintah dengan keluarnya PP Nomor 47 Tahun 2015 yang menyebutkan bahwa desa mempunya wewenang untuk mengatur sumber daya dan arah pembangunan. Hal tersebut membuka peluang desa untuk otonom dalam pengelolaan baik kepemerintahan maupun sumber daya ekonominya. 
Pengembangan basis ekonomi di pedesaan sudah semenjak lama dijalankan oleh pemerintah melalui berbagai program. Namun upaya itu belum membuahkan hasil yang memuaskan sebagaimana diinginkan bersama. Salah satu faktor yang paling dominan adalah intervensi pemerintah terlalu besar, akibatnya justru menghambat daya kreativitas dan inovasi masyarakat desa dalam mengelola dan menjalankan mesin ekonomi di pedesaan. Sistem dan mekanisme kelembagaan ekonomi di pedesaan tidak berjalan efektif dan berimplikasi pada ketergantungan terhadap bantuan pemerintah sehingga mematikan semangat kemandirian.

Berdasarkan asumsi itulah maka sudah seharusnya eksistensi desa mendapatkan perhatian yang serius dari pemerintah pusat dengan lahirnya kebijakan-kebijakan terkait dengan pemberdayaan ekonomi yangdilakukan dengan cara menghimpun dan melembagakan kegiatan ekonomi masyarakat. BUMDes lahir sebagai suatu pendekatan baru dalam usaha peningkatan ekonomi desa berdasarkan kebutuhan dan potensi desa. Pengelolaan BUMDes sepenuhnya dilaksanakan oleh masyarakat desa, yaitu dari desa, oleh desa, dan untuk desa. Cara kerja BUMDes adalah dengan jalan menampung kegiatankegiatan ekonomi masyarakat dalam sebuah bentuk kelembagaan atau badan usaha yang dikelola secaran profesional, namun tetap bersandar pada potensi asli desa. Hal ini dapat menjadikan usaha masyarakat lebih produktif dan efektif.Desa Babalan Lor sebagai salah satu Desa yang baru mendirikan BUMDesperlu menganalisis lebih jauh lagi, apa saja yang menjadi potensi desa yang dapat dijadikan usaha untuk BUMDes.

Desa Babalan Lor merupakan salah satu dari 22 (dua puluh dua) Desa di Kecamatan Bojong Kabupaten Pekalongan yang terletak paling Utara di wilayah Kecamatan Bojong yang berbatasan dengan wilayah Kecamatan Wiradesa. Desa Babalan Lor mempunyai luas wilayah $90.685 \mathrm{Ha}$ dan merupakan daerah dataran rendah, dengan ketinggian $\pm 400 \mathrm{M}$ dari permukaan air laut, terdiri dari empat Dusun, serta terdapat 4 RW dan 15 RT. Adapun batas wilayah Babalan Lor adalah sebagai berikut:

a. Sebelah barat berbatasan dengan Desa Sembung Jambu

b. Sebelah selatan berbatasan dengan Desa Babalan Kidul

c. Sebelah timur berbatasan dengan Kali Sengkarang

d. Sebelah utara berbatasan dengan Desa Delegtukang

Jumlah penduduk di Desa Babalan Lor sebanyak 4.189 jiwa, terdiri dari 2.179 laki-laki dan 2.010 perempuan, dengan jumlah KK ada 970. Mayoritas penduduk Desa Babalan Lor memiliki mata pencaharian sebagai buruh industri, terutama industri rumahan produsen tahu dan usaha konveksi, dimana di Desa 
Babalan Lor ini terkenal dengan Wisata Edukasi Kampung Tahu Ramah Lingkungan. Jumlah Buruh Industri ada 169 orang, Pedagang 165 orang, Buruh Tani 120 orang, Petani 101 orang, Buruh Bangunan 98 orang, Buruh Angkutan 30 orang, Pengusaha 25 orang, TNI POLRI 12 orang, dan lainnya.Melalui metode penelitian tindakan dilengkapi teknik pengumpulan data melalui pengamatan partisipasi, wawancara, dokumentasi, dan diskusi terfokus (focus group discussion), tersusunlah rencana tindakan. Tim Pokja pengabdian kepada masyarakat IAIN Pekalongan melalui program KKN 44 IAIN bersama masyarakat melakukan pendampingan "Pengembangan Potensi Ekonomi Desa Dalam Upaya Meningkatkan Ekonomi Masyarakat Melalui Badan Usaha Milik Desa Sukses Mulyo Desa Babalan Lor Kecamatan Bojong Kabupaten Pekalongan".

\section{KAJIAN OTONOMI DAERAH DAN OTONOMI DESA}

Otonomi daerah merupakan bagian sistem politik yang diharapkan memberi peluang bagi warga negara untuk lebih mampu menyumbangkan daya kreatifitas-nya. Dengan demikian, otonomi daerah merupakan kebutuhan dalam era globalisasi dan reformasi. Tanpa otonomi daerah, masyarakat akan mengalami kesulitan menempatkan diri sejajar dengan manusia-manusia lain di berbagai Negara pada saat. perdagangan bebas mulai berlaku, Soenyono dalam Malarangeng (2001: 5).

Selanjutnya, menurut Widjaja (2002:76) menyebutkan otonomi daerah adalah kewenangan daerah otonom untuk mengatur dan mengurus kepentingan masyarakat setempat menurut prakarsa sendiri ber-dasarkan aspirasi masyarakat, sesuai dengan peraturan perundang-undangan. Sedangkan daerah otonom, adalah kesatuan masyarakat hukum yang mempunyai batas daerah tertentu berwenang mengatur dan mengurus kepentingan masyarakat setempat menurut prakarsa sendiri berdasarkan aspirasi masyarakat dalam ikatan Negara Kesatuan Republik Indonesia.

Sedangkan secara etimologi, kata otonomi berasal dari bahasa Yunani "autos" yang berarti sendiri dan "nomos" yang berarti aturan. Jadi, otonomi dapat diartikan mengatur sendiri. Selanjutnya penjelasan mengenai otonomi daerah menurut UU No. 32 Tahun 2004 tentang Pemerintahan daerah yaitu:

"otonomi daerah berdasarkan Undang-Undang Nomor 32 Tahun 2004 tentang Pemerintahan Daerah adalah hak, wewenang, dan kewajiban daerah otonom untuk mengatur dan mengurus sendiri urusan pemerintahan dankepentingan masyarakat setempat sesuai dengan peraturan perundang-undangan”. 
Oleh karena itu, Widjaja (2002: 7) menjelaskan bahwa pembangunan daerah sebagai bagian integral dari pembangunan nasional tidak bisa dilepaskan dari prinsip otonomi daerah.

Dalam UU No.32 tahun 2004 tentang pemerintahan daerah disinggung pula perihal pemerintahan desa, yang kemudian secara spesifik diatur dalam Peraturan Pemerintah (PP) No.72 tahun 2005 tentang Desa sebagai salah satu aturan pelaksana dari UU No.32 tahun 2004. Jadi, sebenarnya kini telah ada regulasi yang khusus mengatur desa, namun regulasi itu ada di level PP dan bukan UU. Definisi desa menurut PP No 72 tahun 2005 adalah kesatuan masyarakat hukum yang memiliki batas-batas wilayah yang berwenang untukmengatur dan mengurus kepentingan masyarakat setempat, berdasarkan asal-usul dan adat istiadat setempat yang diakui dan dihormati dalam sistem Pemerintahan Negara Kesatuan Republik Indonesia (NKRI). Secara tersurat, PP ini mengakui adanya otonomi desa dalam bingkai NKRI, itu juga memberikan kewenangan yang cukup besar bagi kepala desa dalam me-laksanakan tugas sebagai kepala pe-merintahan desa.

Kewenangan-kewenangan bagi kepala desa tersebut adalah:memimpin penyelenggaraan pemerin-tahan berdasarkan kebijakan yang di-tetapkan bersama Badan Per-musyawaratan Desa (BPD).mengajukan rancangan Peraturan Desa (Perdes).menetapkan Peraturan Desa yang telah mendapat persetujuan bersama BPD.menyusun dan mengajukan rancangan peraturan desa mengenai AnggaranPendapatandanBelanjaDesa(APBDesa) untuk dibahas dan ditetapkan bersama BPD.membina kehidupan masyarakat desa.membina perekonomian desa.mengoordinasikan pembangunan desa secara partisipatif.mewakili desanya di dalam dan di luar pengadilan dan dapat menunjuk kuasa hukum untuk mewakili sesuai dengan peraturan perundang undangan.melaksanakan wewenang lain sesuai dengan peraturan perundang undangan.

Pengakuan akan otonomi desa juga ada dalam UU No.32 tahun 2004. Dalam UU itu dijelaskan tentang definisi desa, yakni suatu kesatuan masyarakat hukum yang mempunyai susunan asli berdasarkan hak asal usul yang bersifat istimewa, sebagaimana dimaksud dalam penjelasan pasal 18 Undang-Undang Dasar 1945. Basis pemikiran dalam pengaturan mengenai Pemerintahan Desa adalah keanekaragaman, partisipasi, otonomi asli, demokratisasi, dan pemberdayaan masyarakat. Sehingga dapat disimpulkan, baik UU No.32 tahun 2004 maupun PP No. 72 tahun 2005 itu me-mang mengamanatkan adanya desentralisasi kekuasaan bagi pemerintahan desa. 


\section{METODE KEGIATAN PENGABDIAN}

Kegiatan dampingan tentang kampung ramah lingkungan melalui (program advokasi dan pengelolaan bank sampah dalam peningkatan ekonomirumah tangga ini dilaksanakan melalui pendekatan multidisipliner. Tujuannya adalah agar target sasaran serta outcomes yang diharapkan tercapai dengan baik. Adapun model-model pendekatandan strategi yang dilakukan adalah sebagai berikut:

a) Pendekatan ketokoh masyarakat

b) Sosialisasi

c) FGD (FocusGroup Discussion)

d) Pembekalan

e) Evaluasi

Beberapa strategi di atas diharapkan mampu mencapai hasil yang diinginkan dalam pelaksanaan program kegiatan pemberdayaan masyarakat tentang kampung ramah lingkung melalui optimalisasi bank sampah sehingga masyarakat Babalan lor dapat meningkatkan ekonomi rumah tangga.

Pencapaian terhadap tujuan yang ingin dicapai dalam program pemberdayaan ini sangat ditentukan oleh langkah-langkah sistematis yang dilakukan olehtim pendamping bersama pihak-pihak yang terlibat dalam program ini. Langkah-langkah yang dilakukan adalah sebagai berikut; pertama, Mapping. Pendataan dilakukan terhadap berbagai masalah yang terjadi di Babalan lor terutama masalah-masalah yang dikategorikan sebagai akibat dari masalahmasalah lingkungan atau permukiman kumuh, baik dari dampak limbah rumah tangga maupun akibat dari limbah industri rumah tangga. Hal ini dilakukan agar program kegiatan ini memiliki arah yang jelas dalam menentukan sasaran. Pendataan juga dilakukan untuk menentukan pihak-pihak (menemukenali masalah dan potensi) didaerah calon dampingan.

Kedua, Sosialisasi. Setelah melakukan pendataan baik masalah yang terjadi maupun calon peserta dampingan, selanjutnya tim melakukan sosialisasi mengenai kegiatan dampingan ini. Sosialisasi disampaikan kepada pihak pemerintah setempat (pihak kelurahan, RWdan RT setempat), dan calon peserta yang akan mengikuti program dampingan. Sosialisasi dilakukan agar program ini mendapatkan dukungan penuh dariparastakeholder.

Ketiga, FGD (Forum Group Discussion). Forum diskusi dilaksanakan oleh tim bersama masyarakat dampingan termasuk tokoh masyarakat untuk memahami kebutuhan bersama dan kegiatan yang bisa dijalankan. Keempat, Evaluasi. Evaluasi dilaksanakan sebagai strategi untuk mengetahui capaian-capaian dari serangkaian kegiatan sebelumnya. Langkah ini dilakukan melalui FGD dengan para peserta,juga para tokoh masyarakat setempat. 
Data yagn termaktub dalam tulisan ini, diperoleh dari Pengumpulan data yang dilakukan dengan teknik wawancara, pengamatan partisipatif, catatan pendampingan, dokumentasi, dan focus group discussion (FGD). Selanjutnya, data yang diperoleh dianalisa dengan tekni analisis deskriptif kualitatif. Teknik analisis deskriptif kualitatif digunakan untuk menjelaskan proses pemberdayaan dari penyadaran, pengilmuan, penerapan, pembentukan dan pengembangan BUMDessesuai dengan potensi lokal dan intensitas kegiatan berkelanjutan.

Kegiatan pengabdian dilaksanakan di Desa Babalanlor, Kecamatan Bojong, Kabupaten Pekalongan. Pelaksanaan pengabdian kepada masyarakat pada tahun 2018 dengan durasi waktu lima bulan. Pengabdian dengan basis penelitian ini menggunakan pendekatan Community Based Research yang dilakukan secara kualitatif. Pendekatan tersebut digunakan untuk menggali pemahaman yang luas dari masyarakat desa di tingkat mikro, messo, dan makro mengenai potensi desa secara keseluruhan, serta mengkaji arah dan motivasi pembangunan ekonomi perdesaan.

Untuk memperoleh data dan informasi yang tepat, pengumpulan data dilakukan dengan cara: Observasi keadaan desa secara langsung maupun mempelajari dokumen-dokumen milik desa yang menjadi data sekunder. Observasi sudah dilakukan selama 45 (empa puluh lima) hari di Desa Babalan Lor Bersama Tim KKN. Personal interview pada orang-orang kunci (key stakeholder) desa, diantaranya dengan Kepala Desa, Sekretaris Desa, Kadus, Kaur dan Lembaga Pemerintah Desa seperti BPD dan LPMD, serta tokoh masyarakat yang berpengaruh di Desa Babalan Lor. KemudianGroup discussion dilakukan bersama kelompok-kelompok masyarakat yang berpengaruh seperti PKK, pengelola BUMDes terpilih dan karang taruna.Focus group discussion dilakukan bersama perwakilan masing-masing anggota kelompok masyarakat dan lembaga desa sebagai upaya crosscheck atas informasi yang diperoleh dari langkah-langkah pengumpulan data sebelumnya.

Pengabdian ini menggunakan analisis isi (content analysis) untuk menjawab pertanyaan penelitian. Analisis isi didefinisikan sebagai metode riset untuk interpretasi subyektif atas isi data melalui proses klasifikasi sistematis dari pemberian kode dan pengidentifikasian tema atau pola (Wahyuni, 2012). Metode ini meringkas dan mengklasifikasi data dalam jumlah besar menjadi beberapa kategori yang merepresentasikan arti yang sama (Weber (1990) dalam Wahyuni, 2012).

Untuk memastikan validitas dan kredibilitas, penelitian ini menggunakan beberapa cara yaitu validasi responden (member checking) dan triangulasi (Yin, 
2009; Creswell, 2010; Wahyuni, 2012). Triangulasi yang digunakan dalam penelitan ini adalah triangulasi sumber.

Tabel 1

Tahapan Analisis Data

\begin{tabular}{ll}
\hline \hline Analisis Data dan Representasi & \multicolumn{1}{c}{ Keterangan } \\
\hline Pengorganisasian Data & $\begin{array}{l}\text { Membuat dan mengorganisir arsip-arsip } \\
\text { data. } \\
\text { Membaca hasil transcript, membuat catatan } \\
\text { pinggir, } \\
\text { dan membuat inisial kode. }\end{array}$ \\
$\begin{array}{l}\text { Mendeskripsikan data menjadi kode } \\
\text { dan tema }\end{array}$ & $\begin{array}{l}\text { Mendeskripsikan kasus-kasus beserta } \\
\text { konteksnya. }\end{array}$ \\
$\begin{array}{l}\text { Mengklasifikasi data menurut kode } \\
\text { dan tema }\end{array}$ & $\begin{array}{l}\text { Menggunakan kategori yang teragregasi } \\
\text { untuk } \\
\text { membangun tema atau pola. }\end{array}$ \\
Menginterpretasikan data & $\begin{array}{l}\text { 1. Menggunakan interpretasi langsung. } \\
\text { 2. Membangun naturalistic generalization } \\
\text { atas apayang sudah dipelajari. }\end{array}$ \\
& $\begin{array}{l}\text { Menampilkan gambaran yang dalam dan } \\
\text { terinci dari } \\
\text { kasus-kasus yang diteliti meng-gunakan } \\
\text { narasi, tabel,dan gambar. }\end{array}$ \\
\hline Menampilkan dan memvisuaslisasian &
\end{tabular}

Sumber: Adaptasi dari Creswell (2010) dalam Kusuma (2015)

\section{HASIL PENGABDIAN PEMBERDAYAAN BUMDES}

Keberadaan BUMDes tidak dipungkiri membawa perubahan di bidang ekonomi dan sosial. Kontribusi BUMDes terutama dalam bentuk Pendapatan Asli Desa, dimana keuntungan bersih BUMDes dialokasikan untuk pemasukan Desa. Keuntungan BUMDes dialokasikan untuk beberapa pihak dengan prosentase yang berbeda. Dari penilaian hasil analisis masyarakat bersama tim pokja pemberdayaan kepada masyarakat bersama mahasiswa KKN ditemukan bahwa Babalan Lor memiliki potensi yang dapat dikelola BUMDes. Adapun potensi masayarakat yang menjadi bahan pertimbangan dalam mendirikan BUMDes Sukses Mulyo Desa Babalan Lor antara lain:

a. Banyaknya produsen tahu, melalui berbagai olahan tahu dapat dipasarkan sebagai oleh-oleh khas wisata Kampung Tahu Ramah Lingkungan. 
b. Kerajinan hasil dari pengolahan sampah anorganik dapat pula menjadi oleh-oleh khas wisata Kampung Tahu

c. Pupuk hasil dari pengolahan sampah organik dapat pula menjadi oleh-oleh khas wisata Kampung Tahu

d. Hasil Perkebunan dan Pertanian khas Desa Babalan Lor

e. Sarana dan Prasarana konveksi, pertanian dan lainnya

f. SDM yang berkompeten

g. Serta potensi-potensi usaha lainnya.

Potensi masyarakat bukan hanya soal sumber ekonomi tetapi juga apa yang selama ini menjadi keluhan masyarakat, hal tersebutlah yang menjadi peluang untuk berdirinya BUMDes. Dari respon yang disampaikan peserta, peserta menunjukan sikap positif terhadap pendirian dan pengelolaan BUMDes yang disampaikan oleh pemateri. Hal ini ditunjukkan oleh perwakilan BPD dan LPMD yang aktif bertanya dan keinginan untuk menindaklanjuti hasil penyuluhan melalui Musyawarah desa.

Kegiatan pengembangan potensi untuk usaha BUMDes yang ada di desa Babalan Lor diharapkan dapat ditindaklanjuti, dengan cara mengadakan pelatihan yang dapat menunjang pengelolaan BUMDes yang lebih baik. Tujuannya adalah menjadikan desa memiliki tingkat perekonomian mandiri yang baik. Untuk kedepannya, sebaiknya para akademisi atau pihak universitas memfasilitasi desa-desa lainnya untuk pengembangan lembaga yang ada di desa karena menurut pengamatan penulis, masih sangat jarang program-program yang bernuansa pengembangan manajemen bagi lembaga di desa. PKM yang cukup sering dilakukan di desa biasanya menyasar sektor UMKM atau sektor usaha, padahal, lembaga seperti BUMDes juga memerlukan pembimbingan atau konsultasi dari pihak akademisi. Implikasi pendampingan ini berkaitan dengan pembangunan dan pemberdayaan masyarakat terutama dalam mengembangkan kemampuan berusaha, peningkatan pengetahuan, keterampilan dan sikap yang akan berdampak pada peningkatan pendapatan. Temuan penelitian juga mampu menumbuhkan dan memupuk jiwa kewirausahaan bagi masyarakat desa serta menumbuhkan rasa tanggung jawab terhadap sebuah kebijakan.

Desa Babalan Lor Kecamatan Bojong Kabupaten Pekalongan,baru mempunyai BUMDes sebagai lembaga perekonomian masyarakat. Jika dilihat dari potensinya, desa ini memiliki potensi besar untuk dikelola BUMDes sebagai penampung kegiatan-kegiatan ekonomi masyarakat dan lembaga pelayanan publik masayarakat. Letak geografis Desa Babalan Lor Kecamatan Bojong Kabupaten Pekalongan yang berada di perbatasan Kecamatan Bojong dan Kecamatan Wiradesa serta berada dekat dengan jalan tol merupakan peluang 
besar yang bisa dimanfaatkan dengan pendirian BUMDes. Selain itu, mengacu pada tujuan pendirian BUMDes, potensi masayarakat bukan saja pada peluang komersial, potensi masyarakat juga mengenai layanan publik yang berhubungan dengan kesejahteraan masyarakat yang belum terpenuhi di desa Desa Babalan Lor Kecamatan Bojong Kabupaten Pekalongan.

Beberapa Masalah yang masih ada di Masyarakat Desa Babalan Lor adalah ketika ada banyak kunjungan di Kampung Tahu, tentunya mereka banyak yang membeli oleh-oleh khas wisata seperti pada tempat wisata pada umumnya. Namun di Kampung Tahu Desa Babalan Lor ini pelayanan dan fasilitas untuk pusat oleh-oleh masih belum tertata dan belum menyediakan stok yang banyak sehingga sering kali pengunjung sebagai pembeli berdesak-desakan bahkan tidak kebagian oleh-oleh yang dijual karena stok habis. Selain itu kurangnya tenaga profesional yang melayani pengunjung menjadikan pelayanan kurang maksimal. Hal tersebut adalah salah satu bentuk masalah yang dapat dikategorikan sebagai masalah pemasaran produk olahan tahu yang seharusnya dapat dikembangkan lagi.

Masalah lain adalah banyaknya usaha konveksi di Desa Babalan Lor ini belum terpenuhi dengan pusat pembelian perlengkapan yang lebih dekat. Pemasaran produk khas produksi Desa juga belum ada. Padahal potensi dengan sering adanya kunjungan di kampung tahu dapat menjadi peluang usaha bagi Desa. Masalah sosial yang sering terlihat adalah banyaknya anak-anak punk yang sering menggunakan daerah sekitar taman Kampung Tahu sebagai tempat mereka sehingga sering kali merusak pandangan pengunjung dan mengurangi citra baik Desa. Padahal anak punk itu bisa dari daerah luar Babalan Lor. Oleh sebab itu perlu adanya SDM yang memadai untuk mengelola dan menjaga wilayah Kampung Tahu pada Khususnya dan perlu adanya penyuluhan sosial untuk orang tua dan juga anak-anak sekitar agar dapat terhindar dari pengaruh buruk.

Masalah Lingkungan Sampah dan Sungai yang saat ini sudah baik perlu dijaga dengan baik, sudah adanya Bank Sampah yang mengelola sampah anorganik menjadi berbagai macam kerajinan, TPS 3R yang mengolah sampah menjadi pupuk. Produk kerajinan dan pupuk ini sering kali dilirik oleh pengujung dan tidak sedikit pula yang membeli terutama pupuk, hal ini tentu dapat menjadi peluang usaha untuk bagaimana membuat pemasaran produk yang lebih baik.

Dari uraian beberapa masalah di atas tentunya diharapkan dapat menjadi gambaran untuk menggali potensi ekonomi di Desa Babalan lor agar dijadikan 
sebagai bentuk usaha di BUMDes Sukses Mulyo dengan tujuan untuk meningkatkan ekonomi masyarakat desa.

Pada AD ART BUMDes Sukses Mulyo juga telah ditetapkan beberapa jenis usaha yang akan dilaksanakan, namun pada peraturan tersebut usaha BUMDes dapat dikembangkan sesuai dengan perkembangan potensi yang ada.

ART BAB VI Pasal 9:

(1) Jenis usaha BUMDes Sukses Mulyo DesaBabalan Lor meliputi usaha-usaha antara lain:

a. Pelayanan jasa yang meliputi:

1. LembagaKeuanganDesa(LKD)

2. SewaBarang/Kios

b. Pengelolaan Kios Desa yang memasarkan:

1. Hasilpertanian;

2. Sarana PrasaranaPertanian;

3. Hasil home industry;

4. Hasil Kerajinanrakyat;

c. Bahan Pokok Makanan.

d. Pengelolaan Usaha Perikanan, Perkebunan danPertanian

(2) Pengembangan usaha BUMDes Sukses Mulyo DesaBabalan Lor dapat dikembangkansesuaidenganpotensidankemampuanyangada.

Sementara itu dari hasil analisis kami ditemukan bahwa Desa Babalan Lor memiliki potensi dalam mendirikan BUMDes. Adapun potensi masayarakat yang menjadi bahan pertimbangan dalam mendirikan BUMDes antara lain:

a. Banyaknya produsen tahu, melalui berbagai olahan tahu dapat dipasarkan sebagai oleh-oleh khas wisata Kampung Tahu

b. Kerajinan hasil dari pengolahan sampah anorganik dapat pula menjadi oleh-oleh khas wisata Kampung Tahu

c. Pupuk hasil dari pengolahan sampah organik dapat pula menjadi oleh-oleh khas wisata Kampung Tahu

d. Hasil Perkebunan dan Pertanian khas Desa Babalan Lor

e. Sarana dan Prasarana konveksi, pertanian dan lainnya

f. SDM yang berkompeten

g. Serta potensi-potensi usaha lainnya.

Pada dasarnya di Desa Babalan lor sudah diadakan sosialisasi dan pembentukan BUMDes melalui program KKN berbasis prodi angakatan 44 IAIN Pekalongan. Pada tahap awal telah dilakukan identifikasi masalah dan potensi dan selanjutnya pada kegiatan lokakarya mini tanggal 13 Mei 2018 dilaksanakan sosialisasi, FGD dan pembentukan pengurus BUMDes. Tahap 
selanjutnya adalah Musyawarah Desa pada tanggal 25 Mei 2018 yaitu penyusunan AD ART dan Revisi Susunan Kepengurusan BUMDes. Tindak lanjut berikutnya adalah penerbitan SK pengurus dan Perdes BUMDes Sukses Mulyo. Semua kegiatan tersebut tidak lepas dari kerjasama TIM KKN beserta Lembaga Desa dan Tokoh Masyarakat.

Dengan adanya sosialisasi dan pembentukan BUMDes diharapkan masyarakat dapat mengetahui dan memahami mengenai BUMDes. Sehingga masyarakat yang mempunyai potensi-potensi yang dapat dikembangkan melalui BUMDes dapat dimanfaatkan.

Dalam konteks peran kelembagan Badan Usaha Milik Desa dalam membantumasyarakat untuk pengembangan ekonominya diharapkan dapat memberikan kontribusi yang positif terutama dalam hal akses modaldan pengembangan usaha masyarakat. Adapun usaha-usaha masyarakat di Desa Babalan Lor dalam melaksanakan aktivitas ekonomi yaitu bergerak pada sektorperdagangan, pertanian peternakan, industri kecil dan jasa.

Kemudian, kontribusi lain yang diharapkan nantinya dari keberadaan kelembagaan BUMDes di Babalan Lor adalah pangaturan pengelolaan pusat oleh-oleh wisata kampung tahu dan bidang usaha lainnya dan selanjutnya kelembagaan BUMDes dapatmemberikan kontribusi bagi peningkatan pendapatan desa, memperbanyak pelaku usaha, mengurangi pengangguran dan kemiskinan. Hal di atas sesuai dengan tujuan BUMDes Sukses Mulyo, yaitu; Meningkatkan Sumber PADes. Memberikan Pelayanan terhadap Kebutuhan Masyarakat. Meningkatkan kesempatan berusaha dan mengurangi pengangguran di Pedesaan. Meningkatkan Pendapatan Masyarakat Desa. Dan Mengurangi Kemiskinan.

Keberadaan BUMDes untuk mewujudkan perekonomian desa yang mandiri sangat diperlukan. Melalui BUMDes diharapkan antar lembaga yang ada di masyarakat saling bersinergi untuk lebih maksimal menciptakan kesejahteraan masyarakat yang setara. Bagi pemerintah desa dan lembaga pedesaan di Desa Babalan Lor segera menentukan jenis usaha BUMDes supaya segera lebih efektif dalam menghimpun unit-unit usaha dari masyarakat dan pengelolaan aset-aset desa agar tujuan dari BUMDes untuk menciptakan kesejahteraan masyarakat yang merata. Bagi pemerintah pusat supaya terus menjalankan kebijakan BUMDes ini, kemudian memberi pengawasan serta pelatihan bagi desa-desa dan tetap mengacu pada kesejahteraan masyarakat desa. Karena kebijakan seperti inilah yang lebih efektif diterapkan di tingkat desa, suatu lembaga usaha ekonomi yang berbadan hukum yang dikelola seluruhnya oleh masyarakat desa dan hasilnya untuk masyarakat itu sendiri. 
Desa Babalan lor sudah mengadakan sosialisasi dan pembentukan BUMDes melalui program KKN berbasis prodi angakatan 44 IAIN Pekalongan. Pada tahap awal telah dilakukan identifikasi masalah dan potensi dan selanjutnya pada kegiatan lokakarya mini tanggal 13 Mei 2018 dilaksanakan sosialisasi, FGD dan pembentukan pengurus BUMDes. Tahap selanjutnya adalah Musyawarah Desa pada tanggal 25 Mei 2018 yaitu penyusunan AD ART dan Revisi Susunan Kepengurusan BUMDes. Tindak lanjut berikutnya adalah penerbitan SK pengurus dan Perdes BUMDes Sukses Mulyo. Semua kegiatan tersebut tidak lepas dari kerjasama TIM KKN dan Pemerintah Desa, LPMD, BPD, RW, RT, Tokoh Masyarakat dan masyarakat pada umumnya.

Berikut adalah hasil dari Musyawarah tersebut, diantaranya:

- Peraturan Desa Babalan Lor Nomor 04 Tahun 2018 Tentang Pendirian Badan Usaha Milik Desa Sukses Mulyo

- Keputusan Kepala Desa Babalan Lor Nomor: 141.1 /19 / V / Tahun 2018 Tentang Penetapan dan Pengesahan Susunan Kepengurusan Organisasi Pengelola Badan Usaha Milik Desa Babalan Lor

- Susunan Pengurus Organisasi Pengelola Badan Usaha Milik Desa Sukses Mulyo..

\section{KESIMPULAN}

Badan Usaha Milik Desa yang selanjutnya disebut BUMDes merupakan salah satu alternatif untuk meningkatkan ekonomi di pedesaan. BUMDes lahir sebagai suatu pendekatan baru dalam usaha peningkatan ekonomi desa berdasarkan kebutuhan dan potensi desa. Pengelolaan BUMDes sepenuhnya dilaksanakan oleh masyarakat desa, yaitu dari desa, oleh desa, dan untuk desa. Dari hasil analisis bahwa Desa Babalan Lor memliki banyak potensi yang dapat dikembangkan melalui unit usaha BUMDes, diantaranya pusat oleh-oleh khas Kampung Tahu yang menjual banyak produk kreasi olahan tahu, hasil kerajinan dari Bank Sampah, Pupuk dari TPS 3R, usaha simpan pinjam, dan usaha pemenuhan kebutuhan masyarakat lainnya. BUMDes diharapkan dapat segera dioperasionalkan sehingga segera dapat dirasakan manfaatnya oleh masyarakat yaitu meningkatkan ekonomi masyarakat.

BUMDes diharapkan dapat mewujudkan perekonomian desa yang Mandiri. Melalui BUMDes diharapkan antar lembaga yang ada di masayarakat saling bersinergi untuk lebih maksimal menciptakan kesejahteraan masyarakat yang setara. Bagi pemerintah desa dan lembaga pedesaan di desa Babalan Lor segera melanjutkan proses pendirian BUMDes dengan segaera mendikiran kios yang 
akan dikelola BUMDes supaya segera lebih efektif dalam menghimpun unit-unit usaha dari masyarakat dan pengelolaan aset-aset desa agar tujuan dari BUMDes untuk menciptakan kesejahteraan dan meningkatkan ekonomi masyarakat yang merata segera dapat tercapai.

\section{DAFTAR PUSTAKA}

Anggraeni, Maria Rosa Ratna Sri. 2016. 'Peranan Badan Usaha Milik Desa (BUMDes) pada Kesejabteraan Masyarakat Pedesaan Studi pada BUMDes di Gunung Kidul, Yogyakarta”. MODUS Vol. 28 (2): 155-167

KeputusanKepalaDesa Babalan Lor Nomor: 141.1 /19 / V / Tahun

2018Tentang Penetapan dan Pengesahan Susunan Kepengurusan Organisasi Pengelola Badan Usaha Milik Desa Babalan Lor

M. Zulkarnae, Reza. 2016. "Pengembangan Potensi Ekonomi Melalui Badan Usaha Milik Desa (BUMDes) Pondok Salam Kabupaten Purwakarta”. Jurnal Aplikasi Ipteks untuk Masyarakat Vol 5, No. 1

Peraturan Desa Babalan Lor Nomor 04 Tahun 2018 Tentang Pendirian Badan Usaha Milik Desa Sukses Mulyo

Peraturan Menteri Dalam Negeri Nomor 39 Tahun 2010 Tentang Badan Usaha Milik Desa

Sayuti, Muh. 2011. 'Pelebagaan Badan Usaha Milik Desa (BUMDes) sebagai

Penggerak Potensi Ekonomi Desa dalam Upaya Pengentasan Kemiskinan di

Kabupaten Donggala”. Jurnal ACADEMICA Fisip Untad Vol. 03 No. 02

Sri Kusuma Dewi, Amelia. 2014. "Peranan Badan Usaha Milik Desa (BUMDes)

Sebagai Upaya dalam Meningkatkan Pendapatan Asli Desa (PADes) serta

Menumbubkan Perekonomian Desa". Journal of Rural and Development

Vol. V No. 1.

Suprianto, Novi Kadewi Sumbawati dan Tri Silfi Fatriana. 2017. "Peran Badan Usaha Milik Desa (BUMDes) Terhadap Peningkatan Pendapatan Masyaraka Desa (Studi Kasus pada Badan Usaha Milik Desa (BUMDes) di Desa Karang Dima Kecamatan Labuhan Badas Kabupaten Sumbawa". Jurnal Ekonomi dan Bisnis Vol 14 No 1. 